\title{
Intestinal Absorption of Magnesium from Food and Supplements
}

Kenneth D. Fine, Carol A. Santa Ana, Jack L. Porter, and John S. Fordtran

Department of Internal Medicine, Baylor University Medical Center, Dallas, Texas 75246

\begin{abstract}
The purpose of this study was to measure magnesium absorption over the wide range of intakes to which the intestine may be exposed from food and/or magnesium-containing medications. Net magnesium absorption was measured in normal subjects after they ingested a standard meal supplemented with 0,10 , 20,40 , and $80 \mathrm{mEq}$ of magnesium acetate. Although absorption increased with each increment in intake, fractional magnesium absorption fell progressively (from $65 \%$ at the lowest to $11 \%$ at the highest intake) so that absorption as a function of intake was curvilinear. This absorption-intake relationship was almost perfectly represented by an equation containing a hyperbolic function plus a linear function. Our results are statistically compatible with a magnesium absorption process that simultaneously uses a mechanism that reaches an absorptive maximum, plus a mechanism that endlessly absorbs a defined fraction (7\%) of ingested magnesium. Compared to previous studies of calcium absorption, much less magnesium than calcium was absorbed at intakes above $8 \mathrm{mEq} / \mathrm{meal}$, apparently due to greater restriction of intestinal permeability to magnesium. We also found that magnesium from a high magnesiumcontaining food source, almonds, was just as bioavailable as from soluble magnesium acetate. In contrast, magnesium absorption from commercially available enteric-coated magnesium chloride was much less than from magnesium acetate, suggesting that enteric coating can impair magnesium bioavailability. (J. Clin. Invest. 1991.88:396-402.) Key words: biological availability - calcium - phosphorus - regression analysis • tablets • enteric-coated
\end{abstract}

\section{Introduction}

Normally about $7.4 \mathrm{mEq}(90 \mathrm{mg})$ of dietary magnesium is eaten per meal $(1,2)$. However, when a $\mathrm{Mg}$ supplement is prescribed for suspected or overt $\mathrm{Mg}$ deficiency, $20 \mathrm{mEq}$ of elemental $\mathrm{Mg}$ may be ingested in a single dose. Intake is even higher with use of antacids or laxatives, when $\mathrm{Mg}$ content per dose may be 40 or $80 \mathrm{mEq}$, respectively. Thus, oral intake of $\mathrm{Mg}$ at a single time during the day can vary widely.

The main purpose of this study was to measure net $\mathrm{Mg}$ absorption over the wide range of $\mathrm{Mg}$ loads to which the normal intestine may be exposed. Previous studies on this question, using the metabolic balance method, are inconclusive be-

Address correspondence to Dr. John S. Fordtran, Department of Internal Medicine, Baylor University Medical Center, 3500 Gaston Avenue, Dallas, TX 75246.

Received for publication 23 January 1991 and in revised form 2 April 1991

J. Clin. Invest.

(c) The American Society for Clinical Investigation, Inc.

0021-9738/91/08/0396/07 \$2.00

Volume 88, August 1991, 396-402 cause most reports used only a few subjects, because patients rather than normal subjects were sometimes studied, because the range of $\mathrm{Mg}$ intake was usually not systematically varied, and/or because the reports used balance periods that are too short for valid results. (A 3-wk balance period is required for methodologic accuracy [3, 4].) Nevertheless, King and Stanbury pooled many previously reported metabolic balance studies, and showed that fecal $\mathrm{Mg}$ output was linearly correlated with $\mathrm{Mg}$ intake and that the regression line passed through zero (5). Converting these results to net absorption as a function of intake suggests that $\sim 38 \%$ of ingested $\mathrm{Mg}$ is absorbed, regardless of intake. However, this analysis was limited to intake values between 100 and $500 \mathrm{mg} / \mathrm{d}$, and its conclusion is inconsistent with some of the individual reports from which the pooled data were obtained.

The studies we report in this paper were carried out by a method wherein net absorption can be measured accurately after ingestion of a single meal $(6,7)$. Using this method, net $\mathrm{Mg}$ absorption was measured over a wide range of intakes by supplementing a standard meal with increasing amounts of a soluble $\mathrm{Mg}$ salt, $\mathrm{Mg}$ acetate $(\mathrm{MgAc}) .{ }^{1} \mathrm{We}$ also measured $\mathrm{Mg}$ absorption from an enteric-coated soluble $\mathrm{Mg}$ salt (Mg chloride) and from almonds (a food source high in $\mathbf{M g}$ ).

\section{Methods}

Subjects. Eight subjects aged 25-35 yrs old volunteered for the study, and informed consent was obtained. All volunteers were healthy males, taking no medications. Six did not drink alcohol and two averaged $45 \mathrm{~g}$ of alcohol (two to three beers) per wk; they did not drink during the study. Baseline serum $\mathrm{Mg}$, serum 1,25-(OH $)_{2}$-Vitamin $\mathrm{D}$, and 24-h urinary $\mathbf{M g}$ excretion are given in Table I; all subjects had normal values.

Preparation of the meals and supplements. The meals and supplements given on each experimental day are listed in Table II. All meals included $10 \mathrm{~g}$ of polyethylene glycol (PEG), as a nonabsorbable marker (8), dissolved in $250 \mathrm{ml}$ of deionized water. Food used in the study was prebought to insure uniformity between days and subjects. Portions were weighed in duplicate to the nearest milligram before cooking, and two meals were prepared in a metabolic kitchen. One meal was given to the subjects to eat and the duplicate meal was analyzed. According to dietary tables $(9,10)$, the standard meal contained $435 \mathrm{kcal}$ and the meal with almonds (Table II) contained $676 \mathrm{kcal}$. The average measured content of $\mathrm{Mg}, \mathrm{Ca}$, and $\mathrm{P}$ in the duplicate meals is given in Tables II and III; the amount of ingested $\mathrm{Ca}$ and $\mathrm{P}$ was not constant because of the extra $\mathrm{Ca}$ and $\mathrm{P}$ contained in Slow-Mag (G.D. Searle and Co., Chicago, IL) and almonds, respectively.

Reagent grade $\mathrm{MgAc}$ tetrahydrate (Aldrich Chemical Co., Inc., Milwaukee, WI) was measured in duplicate to the nearest milligram and manually "loaded" into gelatin capsules (Eli Lilly and Co., Indianapolis, IN). One set of capsules was ingested with the meal (immediately before the first bite); the other was analyzed for $\mathrm{Mg}$ content. A similar protocol was followed, on appropriate days, for Slow-Mag ${ }^{\oplus}$ and almonds.

1. Abbreviation used in this paper: $\mathrm{MgAc}$, magnesium acetate. 
Table I. Baseline Laboratory Values

\begin{tabular}{|c|c|c|c|}
\hline Subject & Serum $\mathbf{M g}$ & $\begin{array}{c}\text { Serum } \\
1,25-(\mathrm{OH})_{2-}^{-} \\
\text {Vitamin D }\end{array}$ & $\begin{array}{l}\text { 24-h urinary } \\
\text { Mg excretion }\end{array}$ \\
\hline & $m E q / l i t e r$ & $p g / m l$ & $m E q / d$ \\
\hline Normal range & $1.4-2.1$ & $15-60$ & $>2 \mathrm{mEq} / \mathrm{d}$ \\
\hline $1(\mathrm{JL})$ & 1.9 & 36 & 9.6 \\
\hline 2 (EF) & 1.6 & 41 & 3.2 \\
\hline 3 (AR) & 1.7 & 30 & 17.0 \\
\hline 4 (DD) & 1.6 & 25 & 8.2 \\
\hline $5(\mathrm{JC})$ & 1.6 & 22 & 6.0 \\
\hline $6(C C)$ & 1.7 & 40 & 14.0 \\
\hline $7(\mathrm{MG})$ & 1.8 & 40 & 6.2 \\
\hline $8(\mathrm{JM})$ & 1.6 & 27 & 7.2 \\
\hline
\end{tabular}

Study design. Each subject underwent eight experiments (Table II) in random order and separated by a minimum of $1 \mathrm{wk}$. On each experimental day, the subject came to the laboratory after an 8-h fast. He underwent gastric intubation by swallowing a small caliber polyvinyl tube with a mercury weighted tip, and gastrointestinal lavage was performed using a poorly absorbable solution (11). This lavage is similar to that routinely used to cleanse the colon for colonoscopy.

After this lavage was complete, the subject removed his tube (time -zero). $4 \mathrm{~h}$ later, the subject voided urine (which was discarded) and a 10-h urine collection then began; immediately thereafter, he ingested the supplement and began eating the meal. $10 \mathrm{~h}$ after ingesting the $\mathrm{Mg}$ load, sufficient time for unabsorbed contents to reach the colon (12, 13), the subject voided to complete a 10-h urine collection, another small caliber tube was placed in the stomach, and a second lavage was undertaken for a 4-h period. The rectal effluent from this lavage was collected for subsequent analysis.

This experimental protocol was approved by the Institutional Review Board for Protection of Human Subjects of Baylor University Medical Center, Dallas.

Analysis. The meals were homogenized in a household blender, and a 50-g aliquot was added to a Kjeldahl flask for acid digestion (wet ashing) with nitric and perchloric acids. When digestion was complete, $\mathrm{Mg}$ and $\mathrm{Ca}$ were measured by atomic absorption spectroscopy and $\mathrm{P}$ was measured colorimetrically (14). The MgAc in gelatin capsules was dissolved in deionized water (acidified with nitric acid) and analyzed for $\mathrm{Mg}$ content by atomic absorption spectroscopy. After manually breaking two Slow-Mag tablets into two pieces (to break the enteric coating) they were dissolved in deionized water (acidified with hydrochloric acid) and measured for $\mathrm{Mg}, \mathrm{Ca}$, and $\mathrm{P}$ in the manner mentioned above. The meal containing almonds was homogenized and measured for $\mathrm{Mg}, \mathrm{Ca}$, and $\mathrm{P}$.

The rectal effluent collected after the second gastrointestinal lavage was homogenized in a commercial blender (model 34BL22; Waring Products, New Hartford, CT) and a 50-g aliquot was acid digested for determination of $\mathrm{Mg}, \mathrm{Ca}$, and $\mathrm{P}$ concentration (as above). Content was derived by multiplying concentration by the volume of rectal effluent collected in $4 \mathrm{~h}$ (usually about 4 liters). This sample was also measured for PEG content (15).

The 10-h urine collection was mixed by manual agitation of the container, and a $25-\mathrm{ml}$ aliquot was acidified with hydrochloric acid and measured for $\mathrm{Mg}$ and $\mathrm{Ca}$ concentration by atomic absorption spectroscopy.

Calculation of absorption and urinary excretion. The amount of PEG recovered in the effluent from the second gastrointestinal lavage was expressed as a percentage of the $10 \mathrm{~g}$ ingested on each experimental day. This was done to confirm full recovery of unabsorbed gastrointestinal contents. PEG recovery was consistently near $100 \%$ (Table II).
Net Mg absorption from the meal and MgAc supplements was calculated with the previously derived formula (7):

Net $\mathrm{Mg}$ absorption from meal and supplement

$=\mathrm{Mg}$ ingested in meal and supplement

- [Mg in effluent after meal and supplement

$-\mathrm{Mg}$ in effluent after water].

For example, if the lavage effluent contained $8 \mathrm{mEq}$ after ingestion of a meal and supplement containing $14 \mathrm{mEq}$, and $1 \mathrm{mEq}$ after ingestion of only water, then net $\mathrm{Mg}$ absorption $=[14-(8-1)]=7 \mathrm{mEq}$. Similar measurements for net $\mathrm{Ca}$ and $\mathrm{P}$ absorption were also carried out. Intake and absorption from the meal can be approximately converted to daily intake and absorption by multiplying meal intake and meal absorption by 3 (16). Fractional absorption was calculated as (net absorption/intake $\times 100$ ).

$\mathrm{Mg}$ absorption from the three different $10-\mathrm{mEq} \mathrm{Mg}$ supplements (MgAc, Slow-Mag ${ }^{\star}$, and almonds) was calculated with the following formula:

$\mathrm{Mg}$ absorption from supplement

$=$ Measured amount of magnesium in supplement

- [Mg in effluent after meal and supplement

- $\mathrm{Mg}$ in effluent after meal and placebo].

This method of calculation removes absorption of meal $\mathrm{Mg}$ from the net absorption equation, allowing a more clear-cut comparison of $\mathrm{Mg}$ absorption from the three supplements.

10-h urinary $\mathrm{Mg}$ and $\mathrm{Ca}$ excretion was calculated by multiplying cation concentration by $10-\mathrm{h}$ urine volume. Percent of absorbed $\mathrm{Mg}$ excreted in urine in $10 \mathrm{~h}$ was calculated with the following formula:

Percentage of absorbed $\mathrm{Mg}$ excreted in urine

(Urinary $\mathrm{Mg}$ excretion after meal and supplement

$=-$ Urinary $\mathbf{M g}$ excretion after fast $) \times 100$.

Net $\mathrm{Mg}$ absorption from meal and supplement

Statistical analysis. A computerized analysis of variance combined with a two-tailed $t$ test was used to test for significance; results were deemed significantly different when $P \leq 0.05$.

\section{Results}

Net magnesium absorption and urinary magnesium excretion. The data used to calculate net $\mathrm{Mg}$ absorption under various experimental conditions are given in Table II. Net $\mathrm{Mg}$ absorption increased with increasing $\mathbf{M g}$ intake, but fractional $\mathbf{M g}$ absorption fell progressively (from 65 to $11 \%$ ) as $\mathrm{Mg}$ intake was increased from 3 to $80 \mathrm{mEq}$. Thus, $\mathrm{Mg}$ absorption was not a linear function of $\mathrm{Mg}$ intake.

Several curve-fitting methods were applied to the data from experiments 1-5, using individual results of net $\mathrm{Mg}$ absorption from each subject at all levels of intake (rather than mean results). Analysis by the double reciprocal (Lineweaver-Burk) method (17), as well as single reciprocal methods (Hanes and Eadie-Hofstee, and their reciprocals [18]) found MichaelisMenten equations and curves inconsistent with the observed data. Because these reciprocal methods can be inaccurate and/ or imprecise (18), computerized nonlinear least squares regression analysis (18-22) was used to find the Michaelis-Menten equation that best fit the data in terms of the lowest mean squared error (software was from SAS Institute, Inc., Cary, NC). The resultant equation (and curve), however, was also inconsistent with the data. Thus, statistically our results did not 


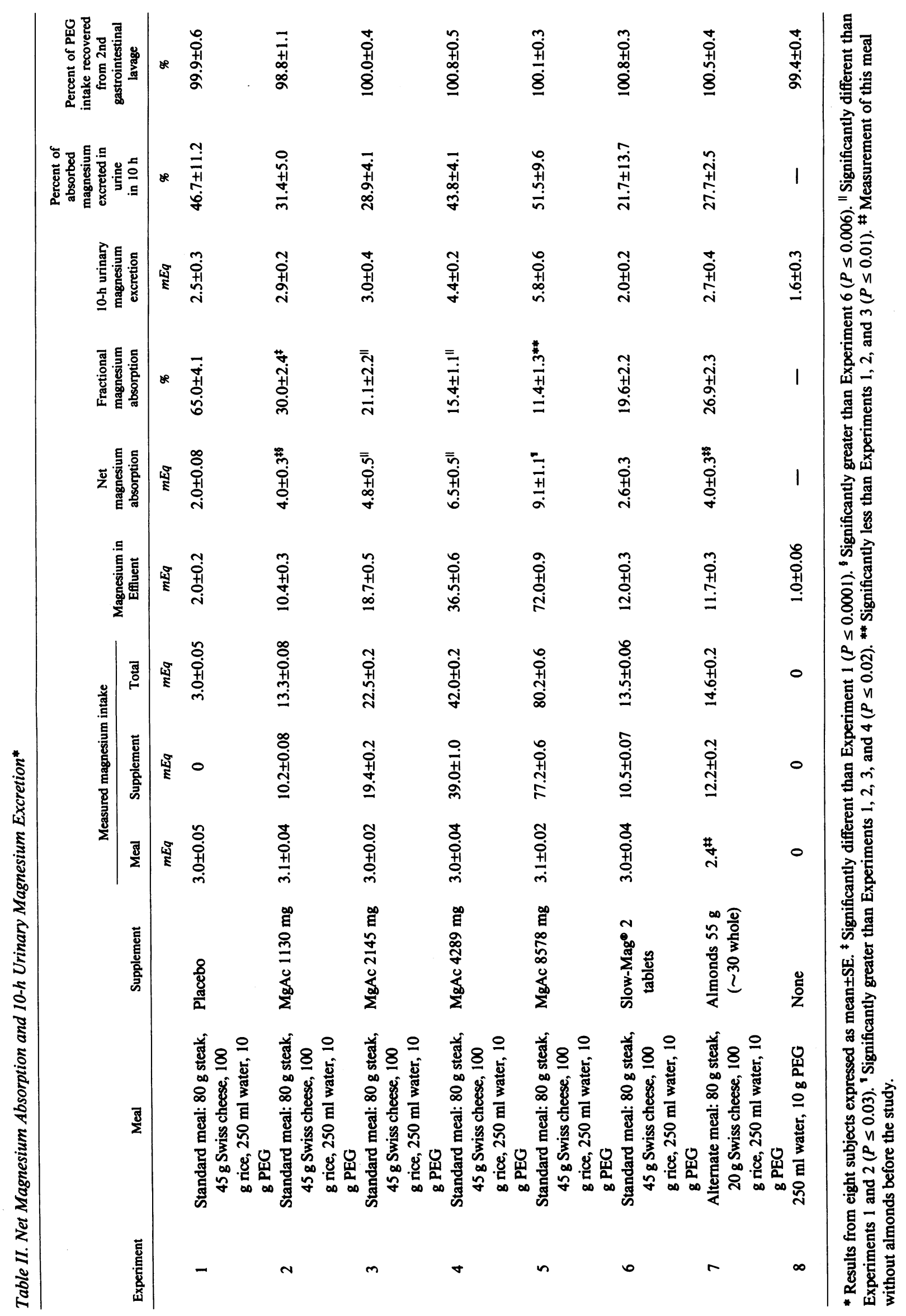


Table III. Net Calcium and Phosphorus Absorption and 10-h Urinary Calcium Excretion*

\begin{tabular}{|c|c|c|c|c|c|c|c|c|}
\hline Experiment & Mg source & $\begin{array}{c}\text { Calcium } \\
\text { intake }\end{array}$ & $\begin{array}{l}\text { Net } \\
\text { calcium } \\
\text { absorption }\end{array}$ & $\begin{array}{l}\text { Fractional } \\
\text { calcium } \\
\text { absorption }\end{array}$ & $\begin{array}{l}\text { 10-h urinary } \\
\text { calcium } \\
\text { excretion }\end{array}$ & $\begin{array}{l}\text { Phosphorus } \\
\text { intake }\end{array}$ & $\begin{array}{l}\text { Net } \\
\text { phosphorus } \\
\text { absorption }\end{array}$ & $\begin{array}{l}\text { Fractional } \\
\text { phosphorus } \\
\text { absorption }^{\ddagger}\end{array}$ \\
\hline & & $m E q$ & $m E q$ & $\%$ & $m E q$ & mmol & $\mathrm{mmol}$ & $\%$ \\
\hline 1 & $\begin{array}{l}\text { Standard meal } \\
+ \text { placebo }\end{array}$ & $15.4 \pm 0.1$ & $4.6 \pm 0.4$ & $29.9 \pm 2.9$ & $3.0 \pm 0.5$ & $13.3 \pm 0.1$ & $9.7 \pm 0.4$ & $72.5 \pm 2.9$ \\
\hline 2 & $\begin{array}{l}\text { Standard meal } \\
\quad+10.2 \mathrm{mEq} \mathrm{MgAc}\end{array}$ & $15.5 \pm 0.1$ & $4.0 \pm 0.4$ & $25.9 \pm 2.9$ & $3.1 \pm 0.6$ & $13.4 \pm 0.1$ & $7.5 \pm 0.4^{8}$ & $55.8 \pm 2.8^{8}$ \\
\hline 3 & $\begin{array}{l}\text { Standard meal } \\
\quad+19.4 \mathrm{mEq} \mathrm{MgAc}\end{array}$ & $15.4 \pm 0.1$ & $3.7 \pm 0.5$ & $24.5 \pm 3.7$ & $3.3 \pm 0.6$ & $13.3 \pm 0.1$ & $6.3 \pm 0.5^{5}$ & $47.1 \pm 3.4^{8}$ \\
\hline 4 & $\begin{array}{l}\text { Standard meal } \\
\quad+39.0 \mathrm{mEq} \mathrm{MgAc}\end{array}$ & $15.4 \pm 0.1$ & $3.9 \pm 0.6$ & $25.4 \pm 3.8$ & $3.9 \pm 0.5$ & $13.2 \pm 0.1$ & $4.8 \pm 0.7^{11}$ & $37.0 \pm 5.4^{\prime \prime}$ \\
\hline 5 & $\begin{array}{l}\text { Standard meal } \\
\quad+77.2 \mathrm{mEq} \mathrm{MgAc}\end{array}$ & $15.4 \pm 0.1$ & $3.7 \pm 0.7$ & $24.0 \pm 4.2$ & $4.9 \pm 0.5$ & $13.3 \pm 0.1$ & $3.8 \pm 0.6^{\prime}$ & $28.1 \pm 4.8^{\prime}$ \\
\hline 6 & $\begin{array}{l}\text { Standard meal } \\
+10.5 \mathrm{mEq} \mathrm{Mg} \text { in } \\
2 \text { Slow-Mag }{ }^{\oplus} \text { tabs }\end{array}$ & $26.7 \pm 0.1^{\ddagger}$ & $7.2 \pm 1.0^{\ddagger}$ & $27.0 \pm 3.4$ & $3.1 \pm 0.7$ & $13.2 \pm 0.1$ & $9.5 \pm 0.6$ & $71.9 \pm 4.9$ \\
\hline 7 & $\begin{array}{l}\text { Alternate meal } \\
+12.2 \mathrm{mEq} \mathrm{Mg} \text { in } \\
\text { almonds }\end{array}$ & $14.3 \pm 0.2$ & $2.0 \pm 0.3^{* *}$ & $14.5 \pm 2.4^{* *}$ & $3.1 \pm 0.6$ & $17.4 \pm 0.2$ & $8.2 \pm 0.6$ & $47.0 \pm 3.5^{5}$ \\
\hline 8 & Fast & 0 & - & - & $1.5 \pm 0.3$ & 0 & - & - \\
\hline
\end{tabular}

${ }^{*}$ Results from eight subjects expressed as mean \pm SE. ${ }^{*}$ Higher Ca intake and absorption due to $11 \mathrm{mEq}$ of Ca in two Slow-Mag ${ }^{\circ}$ tablets. ${ }^{8} \mathrm{Sig}-$ nificantly lower than Experiment $1(P \leq 0.01)$. "Significantly lower than Experiments 1 and $2(P \leq 0.003)$. 'Significantly lower than Experiments 1,2 , and $3(P \leq 0.004){ }^{* *}$ Significantly lower than Experiment $2(P \leq 0.0005$, see text).

conform well to a hyperbola derived from the Michaelis-Menten equation.

To explore the possibility that the net absorption results might conform to a hyperbolic function plus a linear function, nonlinear regression analysis was used to find an equation of format $y=e^{a+b /(x+1)}+c x$ that best fit the data (statistically). The derived equation, $y=e^{1.286-2.889 /(x+1)}+0.0710 x$, (mean squared error $=2.993$ ) depicts a curvilinear increase in net $\mathbf{M g}$ absorption versus intake that almost exactly matches the mean results at all intakes tested (Fig. 1). Our results are therefore statistically compatible with two simultaneously functioning Mg absorptive processes: a mechanism that reaches an absorptive maximum beginning at an intake of $10-12 \mathrm{mEq}$, and a mechanism that endlessly absorbs $7.1 \%(0.0710)$ of ingested Mg.

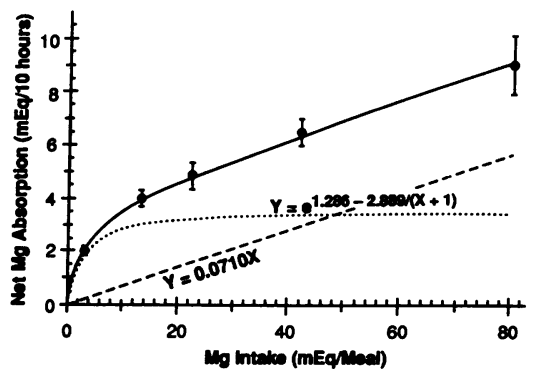

Figure 1. Net Mg absorption versus intake from experiments $1-5$ (Table II) as derived by nonlinear regression analysis. The equation for net absorption, $y$ $=\mathrm{e}^{1.286-2889 /(\mathrm{x}+1)}$ $+0.0710 x$ represents a hyperbolic function plus a linear function. These separate components and their respective equations are shown.
Fig. 2 compares net $\mathbf{M g}$ absorption (Table II, experiments 1-5) with net Ca absorption from similar standard meals supplemented with varying amounts of $\mathrm{Ca}$ carbonate; the $\mathrm{Ca}$ data were obtained by the same method in normal subjects of similar age, and were published previously $(7,23)$. At very low levels of intake, more $\mathrm{Mg}$ than $\mathrm{Ca}$ is absorbed. At intakes greater than $\sim 8 \mathrm{mEq}$, increasingly more $\mathrm{Ca}$ than $\mathrm{Mg}$ is absorbed.

Fig. 3 shows a comparison of individual and mean $( \pm \mathrm{SE})$ $\mathrm{Mg}$ absorption from the three supplements MgAc, Slow-Mag ${ }^{\oplus}$, and almonds. (The reader is referred to Methods to distinguish "Mg absorption from supplements" from "net $\mathbf{M g}$ absorption.") $\mathrm{Mg}$ absorption from MgAc and almonds was similar, while absorption from Slow-Mag ${ }^{\oplus}$ was less by an average of $67 \%$.

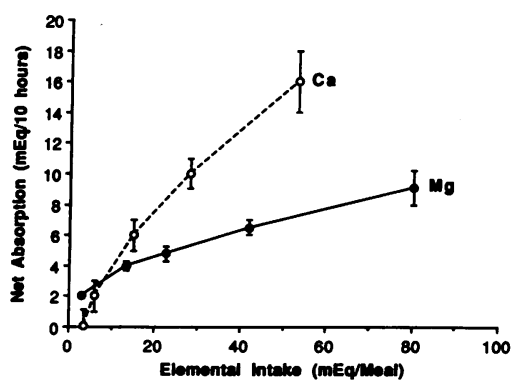

Figure 2. Comparison of net $\mathrm{Mg}$ absorption from experiments $1-5$ (Table II) with net $\mathrm{Ca}$ absorption measured previously from similar meals with and without Ca carbonate. $($ Mean \pm SE values are shown). 


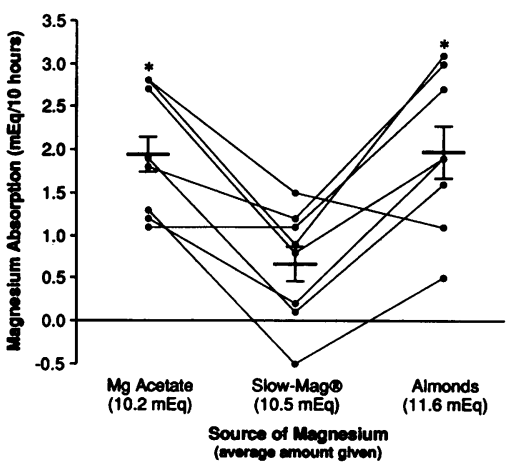

Figure 3. Comparison of $\mathrm{Mg}$ absorption from Mg acetate, Slow-Mag ${ }^{\oplus}$, and almonds. The amount of ingested $\mathrm{Mg}$ was $\sim 10 \mathrm{mEq}$ with each supplement. *Significantly greater absorption compared with Slow-Mag ${ }^{\circledast}(P \leq 0.003)$

Fig. 4 shows 10-h urinary $\mathrm{Mg}$ excretion as a function of net $\mathrm{Mg}$ absorption while the subjects fasted and after they ingested the standard meal without and with MgAc supplementation. Despite moderate individual variation, there was a significant linear correlation $(\mathrm{y}=0.43 \mathrm{X}+1.4, r=0.84, P<0.001)$ between these two parameters. The slope of this line $(0.43)$ indicates that the average percentage of absorbed $\mathbf{M g}$ excreted in urine in $10 \mathrm{~h}$ was $43 \%$ (see also Table II, "percent of absorbed $\mathrm{Mg}$ excreted in urine in $10 \mathrm{~h}$ "). This linear regression did not include values measured with Slow-Mag and almonds because $\mathrm{Ca}$ and $\mathrm{P}$ intake on these days was different. When all eight experiments were considered together, similar results were obtained $(\mathrm{y}=0.45 \mathrm{x}+1.3, r=0.82, P<0.001)$.

Effect of $M g$ on net calcium absorption and urinary calcium. Net $\mathrm{Ca}$ absorption from the standard meal was unaffected by increasing amounts of MgAc (Table III). Net and fractional Ca absorption from the almond meal were significantly lower $(P$ $\leq 0.0005$ ) than from the standard meal plus an equivalent amount of $\mathrm{Mg}$ as $\mathrm{MgAc}$; this was true even though $\mathrm{Ca}$ intake on these two days was approximately the same.

10-h urinary $\mathrm{Ca}$ excretion after the standard meal increased with MgAc supplementation (Table III), and correlated significantly with $\mathrm{Mg}$ intake $(r=0.41, P<0.01)$, net $\mathrm{Mg}$ absorption $(r=0.41, P<0.01)$, and urinary $\mathrm{Mg}$ excretion $(r=0.39, P$ $<0.05)$. The rise in urinary $\mathrm{Ca}$ excretion occurred despite a constant $\mathrm{Ca}$ intake and unaltered net $\mathrm{Ca}$ absorption. After the highest supplemental dose of MgAc (experiment 5), 10-h urinary $\mathrm{Ca}$ excretion exceeded net $\mathrm{Ca}$ absorption (Table III).

Effect of $\mathrm{Mg}$ on net phosphorus absorption. As shown in Table III, increasing amounts of MgAc ingested with the standard meal caused progressive and significant decreases in net and fractional $\mathrm{P}$ absorption $(r=-0.73, P \leq 0.001)$. By contrast, net and fractional $\mathbf{P}$ absorption from the standard meal was unaffected by supplementation with Slow-Mag ${ }^{\oplus}$.

Fractional absorption of $\mathbf{P}$ from the almond meal was significantly lower than from the standard meal and placebo $(P$ $\leq 0.0005$ ). In other words, ingested $P$ was not as efficiently absorbed when Swiss cheese was partially replaced by almonds.

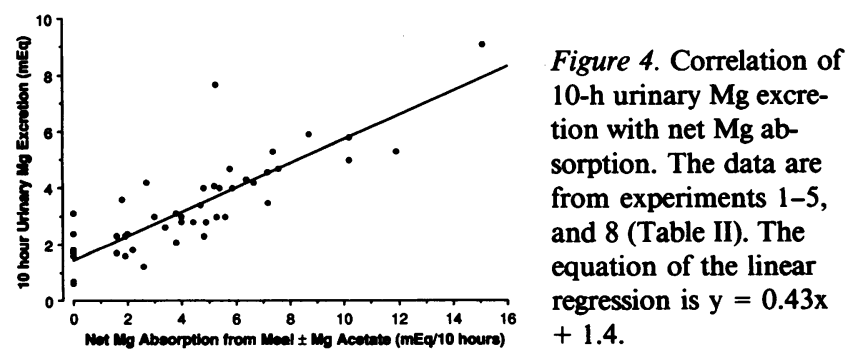

\section{Discussion}

In this study, net $\mathrm{Mg}$ absorption was measured in normal subjects after they ingested a standard meal supplemented with 0 , $10,20,40$, and $80 \mathrm{mEq}$ of MgAc. This allowed a determination of the relationship of $\mathrm{Mg}$ intake and $\mathrm{Mg}$ absorption in normal subjects who had previously been on a free-choice $\mathrm{Mg}$ intake. If the intestine were to undergo "adaptation" in response to chronic ingestion of a low or a high $\mathrm{Mg}$ diet, the relationship we observed between intake and absorption would change in a quantitative sense, but would probably not change in a qualitative sense. As far as we are aware, there is no strong evidence that the intestine does in fact adapt to a chronic high or low $\mathrm{Mg}$ intake, as it does with calcium.

In our studies of normal subjects we found that net absorption rose with each increment in $\mathrm{Mg}$ intake, but that fractional absorption declined in such a way that net $\mathrm{Mg}$ absorption versus $\mathrm{Mg}$ intake was curvilinear (curval at low intakes and linear at high intakes). There are two main ways in which this relationship might be explained mechanistically. The first is that $\mathrm{Mg}$ absorption is entirely passive, with absorption mediated by electrochemical gradients between luminal fluid and plasma; the decrease in fractional absorption at high intakes could be explained if the percentage of ingested $\mathrm{Mg}$ remaining soluble in intestinal fluid fell as intake was increased. This explanation seems unlikely, however, because in other experiments we have shown that even very high $\mathrm{Mg}$ intakes remain nearly completely soluble in fecal fluid (24) and therefore presumably are soluble in intestinal fluid as well. The second possible explanation is that $\mathrm{Mg}$ absorption is mediated by both a saturable carrier and by passive diffusion, with the carrier primarily responsible for mediating absorption when $\mathrm{Mg}$ intake is normal or only slightly elevated and with passive absorption accounting for the continual rise in absorption when intake is elevated further. Evidence that a $\mathbf{M g}$ transport carrier does exist in the human intestine comes from in vitro and in vivo studies of human ileum that showed saturation of net $\mathrm{Mg}$ absorption as $\mathrm{Mg}$ concentration in the perfusate was increased $(25,26)$. The existence of a recessively inherited disorder of $\mathbf{M g}$ absorption (27-29) also supports the existence of carrier-mediated $\mathrm{Mg} \mathrm{ab}$ sorption in normal subjects.

Regardless of the mechanism of $\mathbf{M g}$ absorption and the explanation of the curvilinear relation between $\mathrm{Mg}$ absorption and $\mathrm{Mg}$ intake, the observed results are of interest from several perspectives. One of these is a comparison of $\mathrm{Mg}$ and $\mathrm{Ca}$ absorption. At very low levels of intake, there is net secretion rather than net absorption of $\mathrm{Ca}$ (23). By contrast, there is no suggestion that net secretion of $\mathrm{Mg}$ would occur if $\mathrm{Mg}$ intake was extremely low. On the other hand, at high levels of intake, $\mathrm{Ca}$ absorption is much higher than $\mathrm{Mg}$ absorption; this occurs in spite of the fact that ingested $\mathrm{Ca}$ tends to precipitate in the lower small intestine (30) (and thus becomes unabsorbable) and $\mathrm{Mg}$ tends to remain highly soluble in physiological intestinal fluids (24; Fine, K. D., and J. S. Fordtran, unpublished observations). It thus appears that the normal intestine is somewhat protective against net loss of $\mathrm{Mg}$ when $\mathrm{Mg}$ intake is low and against hyperabsorption of $\mathrm{Mg}$ when intake is high. A relatively restricted passive diffusion across the mucosa of $\mathbf{M g}$ in comparison with $\mathrm{Ca}$ would explain such behavior. Assuming $\mathrm{Mg}$ and $\mathrm{Ca}$ are passively absorbed via a common pathway of fixed size, lower intestinal permeability to $\mathrm{Mg}$ might be due to 
the fact that the effective ionic radius in aqueous solution is larger for $\mathrm{Mg}(8 \AA)$ than for $\mathrm{Ca}(6 \AA)(31)$. Alternatively, a Ca-specific membrane ionophore (i.e., a $\mathrm{Ca}$ channel) might allow passive permeation of $\mathrm{Ca}$ but not $\mathrm{Mg}$.

The results are also of interest in regard to the use of oral $\mathrm{Mg}$ supplements to treat or prevent $\mathbf{M g}$ deficiency. Although a number of $\mathrm{Mg}$ supplements and doses are in current use, the best agent and dose has been heretofore unknown because intestinal absorption of these agents has not been compared in humans. We chose to study MgAc in gelatin capsules so that $\mathrm{Mg}$ would be quickly presented to the intestine in a soluble (absorbable) state. The data in Fig. 1 suggest that a $10-\mathrm{mEq}$ dose of $\mathrm{MgAc}$ would be optimal because fractional absorption falls off fairly steeply with higher doses, leaving a larger fraction of ingested $\mathrm{Mg}$ unabsorbed with the likely consequence of osmotic diarrhea. We also found that $\mathrm{Mg}$ absorption from enteric-coated $\mathrm{Mg}$ chloride (Slow-Mag ${ }^{\circledR}$ ) on average was $67 \%$ less than from $\mathrm{MgAc}$ in gelatin capsules. Since it is not likely that chloride and acetate influenced $\mathrm{Mg}$ absorption directly, our results suggest that the enteric coating on Slow-Mag ${ }^{\circledR}$ tablets (cellulose acetate phthalate) reduced $\mathrm{Mg}$ bioavailability. This could be explained by the fact that cellulose acetate phthalate requires a 3-5-h exposure to gastrointestinal contents before pill contents are completely expelled (32); this delay would presumably reduce the small bowel absorptive area to which ingested $\mathrm{Mg}$ is exposed, and consequently reduce absorption (33).

One of the richest natural food sources of $\mathrm{Mg}$ is almonds, and we found $\mathrm{Mg}$ absorption from almonds to be equal to that from soluble $\mathrm{MgAc}$. In contrast, $\mathrm{Ca}$ and $\mathrm{P}$ were much less bioavailable from almonds than from Swiss cheese (Table III), perhaps because one element interfered with the absorption of the other by formation of insoluble $\mathrm{Ca}_{3}\left(\mathrm{PO}_{4}\right)_{2}$. Alternatively, almonds may contain a substance that reduces $\mathrm{Ca}$ and $\mathrm{P}$ absorption by a separate but unknown mechanism.

As $\mathrm{Mg}$ intake increased, $\mathrm{P}$ absorption progressively decreased. This presumably occurred because $\mathrm{Mg}$ and $\mathrm{P}$ precipitated in the intestinal lumen as $\mathrm{Mg}_{3}\left(\mathrm{PO}_{4}\right)_{2}$. The observed reduction in dietary $\mathrm{P}$ absorption suggests that $\mathrm{MgAc}$ would be an effective $\mathbf{P}$ binder in the treatment of chronic renal failure. Compared to $50 \mathrm{mEq}$ of $\mathrm{Ca}$ acetate, which in a previous study reduced the fractional absorption of dietary $P$ from $77 \%$ to $26 \%$ (34), $50 \mathrm{mEq}$ of $\mathrm{MgAc}$ (extrapolated from the measured reduction with $40 \mathrm{mEq}$ and $80 \mathrm{mEq}$ of $\mathrm{MgAc}$ ) would reduce fractional $\mathrm{P}$ absorption from $77 \%$ to $34 \%$. While there is slightly more $\mathrm{P}$ bound by $\mathrm{Ca}$ acetate per $\mathrm{mEq}$ of cation ingested, because much more $\mathrm{Ca}$ than $\mathrm{Mg}$ is absorbed at a $50 \mathrm{mEq}$ intake (Fig. 2), there is more $P$ bound per $\mathrm{mEq}$ of cation absorbed with $\mathrm{MgAc}$, a desired characteristic of $\mathbf{P}$ binders used in this setting. Unfortunately, the risk of hypermagnesemia and diarrhea from MgAc ingestion would likely limit the clinical usefulness of $\mathrm{MgAc}$ as a $\mathrm{P}$ binder.

In contrast to the marked inhibition of $P$ absorption, increasing $\mathrm{Mg}$ intake had no effect on $\mathrm{Ca}$ absorption. This suggests that $\mathrm{Mg}$ does not inhibit active or passive $\mathrm{Ca}$ absorption, even when $\mathrm{Mg}$ is present in great excess. However, there was an increase in urinary $\mathrm{Ca}$ excretion with increasing $\mathrm{Mg}$ intake and absorption. This effect has been noted previously in metabolic balance studies (35-37) and after intravenous injection of $\mathbf{M g}$ salts $(38,39)$; possible mechanisms have been discussed elsewhere (40-42).

\section{Acknowledgments}

The authors wish to thank Sharon Michael for preparing the manuscript, Diana Santa Ana for technical assistance, Beverly Peters for the graphics, and Patty Franklin, University of Texas-Southwestern Medical Center, for statistical computation.

Dr. Fine is the Reba Perry Powell Fellow in Gastrointestinal Research. This work was supported by U.S. Public Health Service Grant 2-R01-DK37172-06 from the National Institute of Diabetes and Digestive and Kidney Diseases, by the Southwest Digestive Disease Foundation, and by BRSG 507RR05906-05 awarded by the Biomedical Research Support Program, Division of Research Resources, National Institutes of Health

\section{References}

1. U.S. Dept. of Agriculture. 1984. Nutrient intakes: individuals in 48 states, year 1977-78. Nationwide food consumption survey, 1977-78. Report No. I-2.

2. Morgan, K. J., G. L. Stompley, M. E. Zabik, and D. R. Fischer. 1985. Magnesium and calcium intakes of the U.S. population. J. Am. Coll. Nutr. 4:195206.

3. Duncan, D. L. 1967. Nutrition balance techniques and their limitations. Some aspects of the interpretation of mineral balances. Proc. Nutr. Soc. 26:102106.

4. Lentner, C., T. Lauffenburger, J. Guncaga, M. A. Dambacher, and H. G. Haas. 1975. The metabolic balance technique; a critical reappraisal. Metab. Clin. Exp. 24:461-471.

5. King, R. G., and S. W. Stanbury. 1970. Magnesium metabolism in primary hyperparathyroidism. Clin. Sci. (Lond.). 39:281-303.

6. Bo-Linn, G. W., C. A. Santa Ana, S. G. Morawski, and J. S. Fordtran. 1982. Starch blockers-their effect on calorie absorption from a high-starch meal. $N$. Engl. J. Med. 307:1413-1416.

7. Bo-Linn, G. W., G. R. Davis, D. J. Buddrus, S. G. Morawski, C. Santa Ana, and J.S. Fordtran. 1984. An evaluation of the importance of gastric acid secretion in the absorption of dietary calcium. J. Clin. Invest. 73:640-647.

8. Jacobson, E. D., D. C. Bondy, S. A. Broitman, and J. S. Fordtran. 1963. Validity of polyethylene glycol in estimating intestinal water volume. Gastroenterology. 44:761-767.

9. Pennington, J. A. T., editor. 1989. Bowes and Church's Food Values of Portions Commonly Used, 15th ed. J.B. Lippincott Co., Philadelphia.

10. Adams, C. F. 1975. Nutritive Value of American Foods in Common Units. Agriculture Handbook No. 456. U.S. Dept. of Agriculture.

11. Davis, G. R., C. S. Santa Ana, S. G. Morawski, and J. S. Fordtran. 1980. Development of a lavage solution associated with minimal water and electrolyte absorption or secretion. Gastroenterology. 78:991-995.

12. Read, N. W., C. A. Miles, D. Fisher, A. M. Holgate, N. D. Kime, M. A. Mitchell, A. M. Reeve, T. B. Roche, and M. Walter. 1980. Transit of a meal through the stomach, small intestine, and colon in normal subjects, and its role in the pathogenesis of diarrhea. Gastroenterology. 79:1276-1282.

13. Holgate, A. M., and N. W. Read. 1983. Relationship between small bowel transit time and absorption of a solid meal. Influence of metoclopramide, magnesium sulfate, and lactulose. Dig. Dis. Sci. 28:812-819.

14. Fiske, C. H., and Y. Subbarow. 1925. The colorimetric determination of phosphorus. J. Biol. Chem. 66:375-400.

15. Hyden, S. A. 1955. Turbidometric method for determination of higher polyethylene glycols in biological materials. Ann. Agric. Coll. (Sweden). 22:139145.

16. Sheikh, M. S., L. R. Schiller, and J. S. Fordtran. 1990. In vivo intestinal absorption of calcium in humans. Miner. Electrolyte Metab. 16:130-146.

17. Lineweaver, H., and D. Burk. 1934. Determination of enzyme dissociation constants. J. Am. Chem. Soc. 56:658-666.

18. Atkins, G. L., and I. A. Nimmo. 1980. Current trends in the estimation of Michaelis-Menten parameters. Anal. Biochem. 104:1-9.

19. Atkins, G. L., and M. L. G. Gardner. 1977. The computation of saturable and linear components of intestinal and other transport kinetics. Biochim. Biophys. Acta. 465:127-145.

20. Peck, C. C., and B. B. Barrett. 1979. Nonlinear least-square regression programs for microcomputers. J. Pharmacokinet. Biopharm. 7:537-541.

21. Atkins, G. L. 1983. A comparison of methods for estimating the kinetic parameters of two simple types of transport process. Biochim. Biophys. Acta. 732:455-463.

22. Meddings, J. B., R. B. Scott, and G. H. Fick. 1989. Analysis and comparison of sigmoidal curves: application to dose-response data. Am. J. Physiol. 257:G982-G989. 
23. Sheikh, M. S., A. Ramirez, M. Emmett, C. Santa Ana, L. R. Schiller, and J. S. Fordtran. 1988. Role of vitamin D-dependent and vitamin D-independent mechanisms in absorption of food calcium. J. Clin. Invest. 81:126-132.

24. Fine, K. D., C. A. Santa Ana, and J. S. Fordtran. 1991. Diagnosis of magnesium-induced diarrhea. N. Engl. J. Med. 324:1012-1017.

25. Brannan, P. G., P. Vergne-Marini, C. Y. C. Pak, A. R. Hull, and J. S. Fordtran. 1976. Magnesium absorption in the human small intestine. Results in normal subjects, patients with chronic renal disease, and patients with absorptive hypercalciuria. J. Clin. Invest. 57:1412-1418.

26. Phillips, J. D., R. J. Davie, M. R. B. Keighley, and N. J. Birch. 1989. Magnesium absorption in human ileum. J. Am. Coll. Nutr. 8:459. (Abstr.)

27. Paunier, L., I. C. Radde, S. W. Kooh, and D. Frasier. 1965. Primary hypomagnesemia with secondary hypocalcemia. J. Pediatr. 67:945. (Abstr.)

28. Milla, P. J., P. J. Aggett, O. H. Wolff, and J. T. Harries. 1979. Studies in primary hypomagnesaemia: evidence for defective carrier-mediated small intestinal transport of magnesium. Gut. 20:1028-1033.

29. Yamamoto, T., H. Kabata, R. Yagi, M. Takashima, and Y. Itokawa. 1985. Primary hypomagnesemia with secondary hypocalcemia. Report of a case and review of the world literature. Magnesium. 4:153-164.

30. Fordtran, J. S., and W. Locklear. 1966. Ionic constituents and osmolality of gastric and small intestinal fluids after eating. Am. J. Dig. Dis. 11:503-521.

31. Dean, J. A., ed. 1979. Lange's Handbook of Chemistry, 12th ed. McGrawHill Inc., New York.

32. Lin, S. Y., and Y. Kawashima. 1987. Drug release from tablets containing cellulose acetate phthalate as an additive or enteric-coating material. Pharm. Res. (NY). 4:70-74.
33. Davis, S. S., J. G. Hardy, and J. W. Fara. 1986. Transit of pharmaceutical dosage forms through the small intestine. Gut. 27:886-892.

34. Sheikh, M. S., J. A. Maguire, M. Emmett, C. A. Santa Ana, M. J. Nicar, L. R. Schiller, and J. S. Fordtran. 1989. Reduction of dietary phosphorus absorption by phosphorus binders. A theoretical, in vitro, and in vivo study. J. Clin. Invest. 83:66-73.

35. Tibbetts, D. M., and J. C. Aub. 1937. Magnesium metabolism in health and disease. I. The magnesium and calcium excretion of normal individuals, also the effects of magnesium, chloride, and phosphate ions. J. Clin. Invest. 16:491501.

36. Heaton, F. W., and F. M. Parsons. 1961. The metabolic effect of high magnesium intake. Clin. Sci. (Lond.). 21:273-284.

37. Briscoe, A. M., and C. Ragan. 1966. Effect of magnesium on calcium metabolism in man. Am. J. Clin. Nutr. 19:296-306.

38. Womersly, R. A. 1956. Studies on the renal excretion of magnesium and other electrolytes. Clin. Sci. (Lond.). 15:465-471.

39. Chesley, L. C., and I. Tepper. 1958. Some effects of magnesium loading upon renal excretion of magnesium and certain other electrolytes. J. Clin. Invest. 37:1362-1372.

40. Quamme, G. A., and J. H. Dirks. 1980. Intraluminal and contraluminal magnesium on magnesium and calcium transfer in the rat nephron. Am. J. Physiol. 239:F187-F198.

41. Quamme, G. A., and J. H. Dirks. 1980. Magnesium transport in the nephron. Am. J. Physiol. 239:F393-F401.

42. Quamme, G. A., and J. H. Dirks. 1986. The physiology of renal magnesium handling. Renal Physiol. 9:257-269. 